Relations industrielles

Industrial Relations

\title{
Hours of Work by William GOLDNER. Edited by Irvin Bernstein, published by the Institute of Industrial Relations, University of California, Berkeley, 1952, 63 pp., 25 cents.
}

\section{Fabienne Tousignant}

Volume 8, numéro 1, décembre 1952

URI : https://id.erudit.org/iderudit/1023022ar

DOI : https://doi.org/10.7202/1023022ar

Aller au sommaire du numéro

Éditeur(s)

Département des relations industrielles de l’Université Laval

ISSN

0034-379X (imprimé)

1703-8138 (numérique)

Découvrir la revue

Citer ce compte rendu

Tousignant, F. (1952). Compte rendu de [Hours of Work by William GOLDNER. Edited by Irvin Bernstein, published by the Institute of Industrial Relations,

University of California, Berkeley, 1952, 63 pp., 25 cents.] Relations industrielles / Industrial Relations, 8(1), 161-162. https://doi.org/10.7202/1023022ar

Tous droits réservés (C Département des relations industrielles de l’Université Laval, 1952
Ce document est protégé par la loi sur le droit d'auteur. L'utilisation des services d'Érudit (y compris la reproduction) est assujettie à sa politique d'utilisation que vous pouvez consulter en ligne.

https://apropos.erudit.org/fr/usagers/politique-dutilisation/ 
Méthodes et techniques des relations humaines, par GuY-G. Esculier, rapport présenté le 6 juillet 1952 à la Journée d'Etudes du Comité pour l'Amélioration des Relations Humaines dans l'Economie, publié dans Travail et Méthodes, septembre 1952,

3 pp. Editions Science et Industrie,

6 Ave Pierre ler-de-Serbie, Paris XVI.

Au début de son article, l'auteur souligne que la productivité est avant tout un climat et que la condition première de son développement est la sincérité. Toutefois, ce climat n'est pas constitué uniquement par de la bonne volonté, mais par des techniques et des méthodes dont les plus importantes sont celles qui se proposent d'améliorer les relations humaines dans l'entreprise.

Avant de se lancer dans l'étude d'un cas particulier, il faut analyser ce qui peut constituer l'essentiel des divergences ou désaccords apparents vis-à-vis les changements à effectuer afin de ne pas perdre de vue les questions de politique générale. Il est donc bien important de savoir ce que l'on veut et de l'exprimer dans une poli'ique clairement définie.

D'autre part, il ne faut pas seulement savoir ce que l'on veut, mais savoir où l'on en est dans l'application d'un programme d'amélioration des relations humaines. Pour ce, on peut procéder à des enquêtes d'opinion au moyen de questionnaires anonymes dont les réponses devront être objectivement publiées.

Pour obtenir les résultats recherchés, l'auteur suggère des techniques et méthodes groupées sous les cinq catégories suivantes:

1) L'amélioration de la qualité du personnel de tous les échelons par une meilleure sélection à l'embauche et un meilleur choix pour les promotions.

2) L'amélioration de la qualité du personnel de tous les échelons par un perfectionnement constant du personnel en fonction.

3) L'amélioration du climat de l'entreprise par le développement de communications dans les trois sens: de la Direction vers le personnel, du personnel vers la Direction et horizontalement à chaque échelon.

4) L'amélioration du climat de l'entreprise par le développement des liens de solidarité entre l'entreprise et le personnel.

5) L'amélioration du climat de l'entreprise par un intéressement du personnel aux résultats de celle-ci.

Il termine en donnant les règles permanentes essentielles pour obtenir de saines relations humaines dans l'entreprise.

F. T.

Hours of Work by WILliaM GolDNER. Edited by Irvin Bernstein, published by the Institute of Industrial Relations, University of California, Berkeley, 1952, 63 pp., 25 cents.

In this pamphlet, the author studies the problem of hours of work which have progressively been submit ed to reduction while on the other hand, production, on account of the general improvement of machinery and working conditions, has been rising constantly. There is a tendency for uniformity in working time over most of the economy. But there is a problem: low many days a week should be worked, and how should the hours be distributed every day? The element of overtime work and night work is also to be discussed.

The second chapter deals with the movement for shorter hours. And in measuring hours of work, every one should remember the important distinction existing between the scheduled workweek and the actual working time, distinction given by the author, the estimated average weekly working hours, from 1850-1960 is presented in a table and shows the progressive decline in actual working time over a century. Another table draws a good picture of the short-term fluctuations in hours of work which have occurred in manufacturing industries from 1923 to date.

It is interesting to read the historical facts about the early attempts made to obtain shorter hours, from twelve hours a day to eight a day. The arguments, resumed to five, brought by workers and unions in order to reach their goal of shorter work time, are 1) shorter hours are essential to good citizenship; 2) shorter hours are necessary to protect the health of the worker; 3) increased leisure stimulates the demand for the products of industry; 4) shorter hours 
increase the efficiency of labor;

5) shorier hours create more jobs and expand employment.

Besides the bargaining power of the unions, other factors were responsible for shortened working time, factors such as the influence of public opinion, the gradual development of legislative protection and support, and the working of competition.

In a third section is analyzed the effect of changes in hours of work on output efficiency, absenteeism, work injuries. But how short can the workday be?

Mr. Goldner exposes the various Government Regulations on hours of work and some special collective bargaining provisions for hours of works. Related to these provisions, the overtime pay provision is studied in a following chapter.

The author makes some interesting concluding remarks and gives a few suggestions for further reading on the subject of hours of work.

F. T.

\section{Employers' Associations and Collective} Bargaining in New York City, by Jesse Thomas Carpenter; Cornell University Press, Ithaca, New York, 1950, $440 \mathrm{pp}$.

This study by Mr. Carpenter required a tremendous amount of research. It explains "how small-scale businessmen... have formed associations for the purpose of negotiating and administering labor agreements with unions of their employees". It tells why the employer bargaining groups are created, "what forms they take, what powers they exercise, and what procedures they follow". Mr. Carpenter sets forth the major patterns of multiple-employer bargaining and unfolds the various strategies, techniques and pressures that unions and associations exert upon each during the negotiation of group contracts. The Author finally follows the agreement through the many problems that arise during its administration: uniform interpretation, machinery for settling disputes, penalties and punishments upon violators.

The title of this masterly survey could be somewhat misleading. Truly, the Author deals - and generously so - with situations sorted out of the Great City's mass of cases in point. But the book carries more than a local interest. In a manner as "objective" as the subjectmatter will allow, in a fine and simple language, Mr. Carpenter describes and analyses all the intricacies of unionmanagement relations, more specifically in the field of collective bargaining.

Here is, in short, a book worthy of careful and widespread reading.

\section{R. C.}

Revised Profit Sharing Manual, Council of Profit Sharing Industries, First National Tower, Akron 8, Ohio. 1 vol. 317 pages, 1951.

Profit sharing by workers in the United States is far greater than realized. In 1943, its devotees counted some 728 companies; in 1951 there were 12,000 . They increased at the rate of about 100 a month. In 1947, a few companies who had profit sharing plans formed an association to better spread this formula. After four years it has over 300 member companies, representing $350,000 \mathrm{em}$ ployees who shared in profits. In 1948, it published the Profit Sharing Manual. After two editions, it was decided to revise it by eliminating some of the more lengthy passages, bv making certain points clearer and by adding some useful information.

Revised Profit Sharing Manual is divided into three parts, a long introduction of fifty pages, a digest of more than 90 individual plans in force at present and an appendix showing sample contracts of typical profit sharing plans, the membership list of Council of Profit Sharing Industries and a bibliography.

This book does not pretend to be a scientific work but the distinguished collaborators who have taken part in its prepara'ion, wished to present a useful, clear and practical study of the profit sharing formula. In the long introduction, they look at the problem from all angles not neglecting the theoretical and practical objections that could be invoked nor that which experience has taught. The Canadian reader will note that the legal aspects of this formula in our country is covered. In the digest of profit sharing plans, the repetitions that were to be found in Profit Sharing Manual have been avoided; 